[J. Jap. Soc. Starch Sci. Vol.26, No.1 p.3 4 (1978)]

Award Address

\title{
Recent Advances of Starch Science and Starch Technology in Germany
}

\author{
Wolfgang KEMPF \\ Federal Research Center of Cereal and Potato Processing, \\ Institute of Starch and Potato Technology, \\ 12, Schuetzenberg, D-4930 Detmold 1 \\ Federal Republic of Germany
}

Honourable Mr. President,

Honourable Mr. Vice-President,

Ladies and Gentlemen,

Distinguished Colleagues,

Dear Friends:

It is both a great honour and pleasure to me to be with you today and to give a lecture on the occasion of the Annual Meeting 1978 of the Japanese Society of Starch Science at Tokyo. May I thank you from the bottom of my heart for the wonderful opportunity to visit your beautiful country for the second time, to learn the tremendous progress in Japanese Starch Science and Starch Technology, to become acquainted with outstanding Japanese starch experts of international reputation and to see again long-time colleagues and good old friends.

\section{Historical Development}

The professional co-operation between Japan and Germany already started more than twenty years ago, when I was asked by the Starcosa Company at Wunstorf/Hanover, whether I would be ready and willing to assist as consulting starch chemist in modernizing and reorganizing the Japanese potato starch industries on the Northern Hokkaido Island.

This very comprehensive project was conducted by Professor Dr. H. Ohtsuka, Dean of the Faculty of Engineering of the Hokkaido University at Sapporo, and consisted of the planing, erecting and installation of two new modern potato starch plants, one of them provided with
German machineries from Starcosa and Westfalia, whereas the other one was equiped by the Dorr-Oliver Company at Amsterdam, The Netherlands, and Alfa-Laval Company at Tumba, Sweden. The initial detailed written reports were followed by a first visit of Professor Dr. H. Ohtsuka and Dr. K. Iio at Detmold in October 1959 and a meeting with me at New York City in the same month shortly before my return to Germany after a six months study tour throughout the United States. Some time later Professor Dr. H. Ohtsuka introduced me by letter to Dr. S. Suzuki, who prepared and organized my first visit to this country in September 1962. During my three weeks stay in Japan beside many other renowned Japanese starch experts I also became acquainted with Professor Dr. Z. Nikuni, Director of the Institute of Scientific and Industrial Research at the Osaka University.

This first visit of Japan turned out as a great success and was the beginning of a very pleasant and fruitful co-operation as well as the starting-point of a personal friendship between Dr. S. Suzuki and me. This event was followed by two visits of Dr. S. Suzuki at Berlin in August 1970 and at Detmold in October 1975.

The purpose of the third and last visit was the presentation of the Saare-Award to Professor Dr. Z. Nikuni and Dr. S. Suzuki by the Association of Cereal Research at Detmold on the occasion of the last year's 28. Starch Convention 1977 . We all still remember with great respect and much pleasure of the two excellent 
plenary lectures presented by the distinguished guest-speakers on that occasion.

Now, after more than twenty years of successful professional co-operation and very pleasant personal memories I am very, very happy to be here again, because it is always a good thing to be together with nice old friends.

\section{Introduction}

When Dr. S. Suzuki invited me to give a plenary lecture, he suggested recent advances of starch science and starch technology in Germany as topic of this contribution. However, since I know that the application of starch and starch products and consequently also the field of interest in Japan and Germany differ to a considerable extent, I believe that it may be an optimum solution to report on some results of various investigations performed in the Institute of Starch and Potato Technology at Detmold within recent years, because at least the results of one or the other research project will meet the interest of the Japanese starch experts.

I shall finish my speech with a comprehensive survey on recent developments and present stay of the starch and starch derivatives production in both the Federal Republic of Germany and the European Community. Before doing so, I would like to give a short introduction into the organization and research activities of the Federal Research Center of Cereal and Potato Processing at Detmold in general and of the Institute of Starch and Potato Technology in particular.

\section{Federal Research Center of Cereal and Potato Processing}

\section{Institute of Starch and Potato Technology}

5. Maize Starch

6. Wheat Starch

\section{Potato Starch}

8. Starch Sugars

\section{Starch Industries}

\section{Conclusion}

Honourable Mr. President, Honourable Mr. Vice-President, Ladies and Gentleman, Distinguished Colleagues, Dear Friends:

May I thank you very much for your great patience in having listened to me for such a long time. I therefore have to apologize with regard to the length of my lecture. However, it will be quite understandable that my contribution did not cover all research activities carried out in the Institute of Starch and Potato Technology at Detmold within recent years.

Most results of the successful investigations as presented in this lecture have been performed by the scientists W. Kempf, G. Tegge, E. Wilhelm and W. Gschwend. Further research work has been done in the specific field of chemistry and technology of potato processing. Various projects on dried, fried and wet potato products such as dried potatoes, mashed potato powder, potato chips, potato sticks, french fries and other processed potato products which unfortunately could be not considered this time have been successfully studied by the other four researchers of the Institute, W. Bergthaller, B. Putz, K. H. Fehn and P. Voß. Nevertheless, it is sincerely hoped that this presentation offered a comprehensive survey on some chemical and technological aspects of particular interest and importance for the starch industry in my home-country Germany.

May I finally express my deepest gratitude to all my co-workers at Detmold for their actual contributions and pleasant co-operation and particularly to all of you for your very kind attention. 